\title{
Problematika Penerapan Diversi Terhadap Anak Pelaku Tindak Pidana Narkotika
}

\author{
Irwan \\ Fakultas Hukum Universitas Islam Indonesia Yogyakarta Indonesia \\ Jln. Cik Di Tiro No. 1 Yogyakarta Indonesia \\ irwanlalaq@gmail.com
}

\begin{abstract}
This study examines, first, the application of diversion in narcotics crimes committed by children after the enactment of Perma No.4 of 2014 on Guidelines for the Implementation of Diversion in the Juvenile Justice System (SPPA Law); second, the constraints on the application of diversion in narcotics crimes committed by children after the enactment of Perma No. 4 of 2014. This is a normative legal research supported by information from sources using statutory and conceptual approach and analyzes it from a perspective. The results of the study conclude that, first, the application of diversion in narcotics crime according to Perma No. 4 of 2014 has not been implemented. Based on the SPPA Law, the application of diversion can be carried out in cases where the threat is under 7 (seven) years while in Perma No. 4 of 2014 the application of diversion can be carried out for cases where the threat is more than 7 (seven) years but the charges are subsidarity, alternative, or cumulative. One of the charges is that there is a threat of diversion under 7 (seven) years. Second, law enforcers think that narcotics is a criminal offense that is highly charged even though the charges are alternative, where Perma No. 4 of 2014 requires diversion in criminal acts charged with alternative charges, this happens because law enforcers rarely use Perma No. 4 of 2014.
\end{abstract}

Key Words: Children; diversion; investigation

\begin{abstract}
Abstrak
Penelitian ini mengkaji, pertama, penerapan diversi dalam tindak pidana narkotika yang dilakukan oleh anak setelah berlakunya Perma Nomor 4 Tahun 2014 tentang Pedoman Pelaksanaan Diversi dalam Sistem Peradilan Anak; kedua, kendala penerapan diversi dalam tindak pidana narkotika yang dilakukan oleh anak setelah berlakunya Perma Nomor 4 Tahun 2014. Penelitian ini merupakan penelitian hukum normatif yang didukung keterangan narasumber dengan menggunakan pendekatan perundang-undangan dan pendekatan konseptual serta menganalisisnya dengan cara perspektif. Hasil penelitian menyimpulkan bahwa, pertama, penerapan diversi dalam tindak pidana narkotika menurut Perma Nomor 4 Tahun 2014 masih belum dilaksanakan. Berdasarkan UU SPPA, penerapan diversi dapat dilakukan terhadap perkara yang ancamannya di bawah 7 (tujuh) tahun sedangkan dalam Perma Nomor 4 Tahun 2014 penerapan diversi dapat dilakukan terhadap perkara yang ancamanya di atas 7 (tujuh) tahun tetapi dakwaanya bersifat subsidaritas, alternatif, atau kumulatif yang salah satu dakwaannya ada ancaman yang di bawah 7 (tujuh) tahun harus dilakukan diversi. Kedua, penegak hukum beranggapan bahwa tindak pidana narkotika merupakan tindak pidana yang didakwa tinggi sekalipun dakwaannya alternatif di mana Perma Nomor 4 Tahun 2014 mewajibkan diversi dalam tindak pidana yang didakwa dengan dakwaan alternatif, hal ini terjadi karena para penegak hukum jarang menggunakan Perma Nomor 4 Tahun 2014.
\end{abstract}

Kata-kata Kunci : Diversi; penyidik; anak 


\section{Pendahuluan}

Kenakalan anak setiap tahun selalu meningkat. Perkembangan tindak pidana yang dilakukan anak selama ini dirasakan telah meresahkan semua pihak khususnya orang tua. Fenomena meningkatnya perilaku tindak pidana yang dilakukan oleh anak, seolah tidak berbanding lurus dengan usia pelaku. Berbagai upaya pencegahan dan penanggulangan kenakalan anak, perlu segera dilakukan. ${ }^{1}$ Salah satu pencegahan kenakalan anak saat ini melalui penyelenggaraan sistem peradilan anak. Tujuan penyelenggaraan sistem peradilan anak tidak semata mata bertujuan untuk menjatuhkan sanksi pidana bagi anak yang telah melakukan tindak pidana, tetapi lebih difokuskan pada dasar pemikiran bahwa penjatuhan sanksi tersebut sebagai sarana mendukung mewujudkan kesejahteraan anak pelaku tindak pidana.

Ketika anak diduga melakukan tindak pidana, maka sistem peradilan formal yang menempatkan anak dalam status narapidana dapat membawa konsekuensi besar dalam kehidupan anak tersebut. Proses peradilan formal yang memasukkan anak ke dalam penjara ternyata tidak berhasil dan tidak membuat anak tersebut jera dan menjadi pribadi yang lebih baik. Penjara justru membuat anak semakin profesional dalam melakukan kejahatan. Indonesia sendiri telah memiliki peraturan yang mengatur agar anak yang menjadi tersangka tindak pidana tidak diadili dengan sistem peradilan formal yaitu Undang-Undang Nomor 3 Tahun 1997 tentang Pengadilan Anak. Undang-undang tersebut memiliki beberapa kelemahan. Kelemahan dalam peraturan tersebut yang paling terlihat adalah tidak adanya penerapan konsep diversi.

Sebagai upaya mengatasi kelemahan Undang-Undang Nomor 3 Tahun 1997 tentang Pengadilan Anak yang tidak terdapat konsep diversi dan menempatkan anak dalam status narapidana, maka diberlakukan perubahan melalui UndangUndang Nomor 11 Tahun 2012 tentang Sistem Peradilan Pidana Anak (UU SPPA) yang menggunakan menggunakan pendekatan restoratif justice melaui sistem diversi. UU SPPA mengatur mengenai kewajiban para penegak hukum dalam mengupayakan diversi pada seluruh tahapan proses hukum. Diversi adalah pengalihan penyelesaian perkara Anak dari proses peradilan pidana ke proses di luar peradilan pidana².

Ketentuan yang terdapat dalam UU SPPA hanya memungkinkan diversi diberlakukan oleh penyidik berdasarkan kewenangan diskresioner yang

${ }^{1}$ Nandang Sambas, Pembaharuan Sistem Pemidanaan Anak di Indonesia, Yogyakarta, Graha Ilmu, 2010, hlm. 103.

${ }^{2}$ http://www.hukumonline.com/berita/baca/lt5475dd3e4d788/icjr, Aparat Hukum Belum Pabam Arti Diversi. 
dimilikinya dengan cara menyerahkan anak yang berhadapan dengan hukum kepada orang tua, wali atau orang tua asuhnya. Proses peradilan perkara anak sejak ditangkap, ditahan, dan diadili pembinaannya wajib dilakukan oleh pejabat khusus yang memahami masalah anak. ${ }^{3}$ Sebelum memasuki proses peradilan, para penegak hukum, keluarga, dan masyarakat harus mengupayakan proses penyelesaian di luar jalur pengadilan, yakni dengan cara diversi yang berdasarkan pendekatan keadilan restoratif. Konsep pendekatan restorative justice merupakan suatu pendekatan yang lebih menitik beratkan pada kondisi terciptanya keadilan dan keseimbangan bagi pelaku tindak pidana serta korbannya sendiri. ${ }^{4}$

Anak yang melakukan pelanggaran hukum atau yang melakukan tindak kriminal sangat dipengaruhi beberapa faktor lain dari luar diri anak tersebut antaranya adalah pergaulan, pendidikan, dan teman bermain. Tindak pidana yang dilakukan oleh anak pada umumya merupakan proses meniru ataupun terpengaruh tindakan negatif dari orang dewasa atau orang disekitarnya. Anak mempunyai ciri dan karateristik tersendiri, sehingga harus diberlakukan secara berbeda, memperhatikan hak-haknya, kelangsungan hidupnya kelak di masa depan, dan juga harus mempertimbangkan kepentingan terbaik bagi anak tersebut.

Anak yang diduga melakukan tindak pidana, dan diproses melalui UU SPPA harus ditangani oleh penyidik yang khusus menangani perkara anak, jaksa yang juga khusus menangani perkara anak, dan hakim khusus yang menangani perkara anak. Peran aktif dari penegak hukum ini sangat diperlukan sekali dalam menyelesaikan perkara anak agar tidak terjadi pelanggaran terhadap hak-hak anak. ${ }^{5}$ UU SPPA mengatur bahwa diversi dapat diberlakukan hanya terhadap pidana yang ancamannya di bawah 7 tahun dan tindak pidananya bukan merupakan tindak pidana pengulangan.

Di Indonesia terdapat permasalahan dalam penyelesaian terhadap perkara anak. Perkara anak tersebut adalah perkara yang berkaitan dengan narkotika, yang saat ini terdapat 2 dakwaan, yaitu dakwaan pertama diancam dengan penjara di bawah 7 tahun karena dianggap sebagai pemakai dan dakwaan kedua diancam penjara lebih dari 7 tahun karena dianggap memiliki. UU SPPA dalam hal ini tetap menjadi panduan para penegak hukum untuk menyelesaikan

${ }^{3}$ Wirjono Prodjodikoro, Asas-Asas Hukum Pidana Indonesia, PT. Eresco, Bandung, 1989, hlm.34.

${ }^{4}$ http://www.hukumonline.com/berita/baca/lt4e25360a422c2 Jecky Tengens, SH, Pendekatan Restorative Justice dalam Sistem Pidana Indonesia.

${ }^{5}$ Mulyana W, Kusuma, Hukum dan Hak-Hak, Anak, CV. Rajawali, Jakarta, 1986, hlm.3. 
perkara tersebut, namun keadilan restoratif yang diberlakukan oleh peraturan tersebut seperti hilang karena dalam perkara tersebut terdapat 2 dakwaan. Dakwaan yang lebih rendah dapat dijadikan tumpuan untuk memutus dan menerapkan konsep diversi itu kembali.

Perma Nomor 4 Tahun 2014 tentang Pedoman Pelaksanaan Diversi dalam Sistem Peradilan Pidana Anak muncul untuk mengisi kekosongan hukum yang terdapat pada UU SPPA yang tidak mengatur ataupun menjelaskan tentang penerapan diversi terhadap dakwaan yang alternatif. Hakim ataupun aparat penegak hukum lain seharusnya dapat menggunakan Perma Nomor 4 Tahun 2014 tentang Pedoman Pelaksanaan Diversi dalam Sistem Peradilan Pidana Anak untuk pedoman Diversi selain UU SPPA.

Kasus kepemilikan narkoba oleh anak di Kabupaten Langkat dilakukan anak berusia 17 Tahun serta diadili oleh Pengadilan Negeri Binjai dan banding ke Pengadilan Tinggi Medan pada Kamis 6 November 2014. Anak tersebut didakwa atas kepemilikan narkoba dengan dakwaan alternatif yaitu Pasal 111 ayat (1) UU RI No. 35 Tahun 2009 tentang Narkotika dan Pasal 127 ayat (1) huruf a UU RI No. 35 Tahun 2009 tentang Narkotika. Pihak penyidik dan kejaksaan tidak menerapkan diversi dalam kasus ini, sedangkan Pengadilan Negeri Binjai menerapkan dengan panduan Perma Nomo 4 Tahun 2014 tentang Pedoman Pelaksanaan Diversi dalam Sistem Peradilan Pidana Anak. Sebagaimana Pasal 3 Perma a quo bahwa Hakim anak wajib melakukan diversi.

Penyidik yang menilai tidak seharusnya diterapkan diversi akhirnya melakukan banding ke Pengadilan Tinggi Medan. Pengadilan Tinggi Medan mengabulkan banding dari penyidik dan mengubah putusan dari Pengadilan Negeri Binjai dengan menjatuhkan pidana kepada anak selama 3 minggu. Putusan ditetapkan pada Selasa, 24 Februari 2015 oleh H. Bachtiar Hakim Tinggi Pengadilan Tinggi Medan, yang ditunjuk untuk memeriksa dan mengadili perkara tersebut. 6 Dari contoh penyelesaian kasus tersebut dapat diketahui bahwa antar aparat penegak hukum masih terjadi ketidaksepahaman dalam penerapan diversi. Diversi seharusnya dilakukan untuk menjaga hak-hak anak agar tetap terjaga dan di lindungi.

\section{Rumusan Masalah}

Rumusan masalah yang dikaji dalam penelitian ini adalah, pertama, bagaimana penerapan diversi dalam tindak pidana narkotika yang dilakukan oleh anak setelah berlakunya Perma Nomor 4 Tahun 2014 tentang Pedoman

\footnotetext{
${ }^{6}$ Putusan Pengadilan Tinggi Medan Nomor : 6 / PID.Sus.Anak / 2015 / PT.MDN
} 
Pelaksanaan Diversi dalam Sistem Peradilan Anak? Kedua, bagaimana penerapan diversi dalam tindak pidana narkotika yang dilakukan oleh anak setelah berlakunya Perma Nomor 4 Tahun 2014 tentang Pedoman Pelaksanaan diversi dalam Sistem Peradilan Anak?

\section{Tujuan Penelitian}

Adapun penelitian ini bertujuan, pertama, untuk mengetahui penerapan diversi dalam tindak pidana narkotika yang dilakukan oleh anak setelah berlakunya Perma Nomor 4 Tahun 2014 tentang Pedoman Pelaksanaan Diversi dalam Sistem Peradilan Anak; kedua, untuk mengetahui kendala dalam penerapan diversi dalam tindak pidana narkotika yang dilakukan oleh anak setelah berlakunya Perma Nomor 4 Tahun 2014 tentang Pedoman Pelaksanaan Diversi dalam Sistem Peradilan Anak.

\section{Metode Penelitian}

Penelitian ini merupakan penelitian hukum normatif, yang didukung dengan keterangan yang diambil dari narasumber. Penelitian hukum normatif yaitu penelitian melalui studi kepustakaan dengan memperlajari dan menelaah ketentuan-ketentuan hukum yang berlaku, dokumen atau literatur serta melakukan penelitian terhadap peraturan hukum, yaitu dengan menganalisis peraturan hukum dalam sistem pidana sebagai titik tolak penelitiannya. ${ }^{7}$ Pendekatan-pendekatan yang digunakan di dalam penelitian ini adalah perundang-undangan, ${ }^{8}$ dan pendekatan kasus. ${ }^{9}$ Bahan hukum primer, yaitu bahan hukum yang bersifat mengikat yang terdiri dari: (1) Kitab Undang-Undang Hukum Acara Pidana (KUHAP); (2) Kitab Undang-Undang Hukum Pidana (KUHP); (3) Undang-Undang Nomor 35 Tahun 2009 tentang Narkotika; (4) Undang-Undang No. 11 Tahun 2012 tentang Sistem Peradilan Pidana Anak; (5) Perma Nomor 4 Tahun 2014 tentang Pedoman Pelaksaan Diversi dalam Sistem Peradilan Pidana Anak. Bahan hukum sekunder terdiri atas buku dan teori-teori hukum yang membahas konsep diversi. Bahan Hukum Tertier, yaitu jurnal dan internet yang berhubungan dengan konsep diversi. Adapun pengumpulan data dalam penelitian ini dilakukan dengan cara melakukan studi pustaka, yaitu dengan cara mencari dokumen-dokumen yang membahas teori dan asas konsep diversi. Di samping itu, juga dilakukan wawancara dengan narasumbner guna

\footnotetext{
${ }^{7}$ Soerjono Soekanto \& Sri Mamudji, Penelitian Hukum Normatif, Rajawali, Jakarta, 1985, hlm.70.

8 Peter Mahmud Marzuki, Penelitian Hukum Edisi Revisi, Prenadamedia Group, Jakarta, 2016, hlm. 133.

${ }^{9}$ Ibid., hlm. 134.
} 
melengkapi data dalam penelitian ini. Bahan hukum yang telah dikumpulkan dalam penelitian ini akan dianalisis dengan cara preskriptif. ${ }^{10}$

\section{Hasil Penelitian dan Pembahasan}

Penerapan Diversi terhadap Anak Pelaku Tindak Pidana Narkotika Setelah Berlakunya Perma Nomor 4 Tahun 2014 tentang Pedoman Pelaksanaan Diversi dalam Sistem Perdilan Pidana Anak

Pelaksanaan diversi dilatarbelakangi keinginan untuk menghindari efek negatif terhadap jiwa dan perkembangan anak oleh keterlibatannya dengan sistem peradilan pidana. Upaya pengalihan atau ide diversi ini, merupakan penyelesaian yang terbaik yang dapat dijadikan formula dalam penyelesaian beberapa kasus yang melibatkan anak sebagai pelaku tindak pidana. Kewenangan untuk melakukan diversi adalah dari aparat penegak hukum pada masing-masing tingkatan pemeriksaan yaitu pada tingkat penyidikan, penuntutan dan pemeriksaan perkara anak di pengadilan negeri sebagaimana yang dimuat dalam Pasal 7 Undang-Undang Nomor 11 Tahun 2012 tentang Sistem Pidana Peradilan Anak (UU SPPA). Secara khusus pada tingkat penuntutan, acara peradilan pidana anak diatur dalam Bab III Bagian Keempat Pasal 41 dan Pasal 42 UU SPPA. ${ }^{11}$

UU SPPA telah mengatur tentang diversi yang berfungsi agar anak yang berhadapan dengan hukum tidak terstigmatisasi akibat proses peradilan yang harus dijalaninya. Hal ini sesuai dengan yang tercantum dalam Resolusi PBB tentang United Nation Standard Minimum Rules for the Administration of Juvenile Justice (The Beijing Rules). Diversi adalah pemberian kewenangan kepada aparat penegak hukum untuk mengambil tindakan-tindakan kebijaksanaan dalam menangani atau menyelesaikan masalah pelanggar anak dengan tidak mengambil jalan formal antara lain menghentikan atau meneruskan atau melepaskan dari proses peradilan pidana atau mengembalikan atau menyerahkan kepada masyarakat dan bentuk-bentuk kegiatan pelayanan sosial lainnya. ${ }^{12}$

Prinsip perlindungan hukum terhadap anak harus sesuai dengan Konvensi Hak-Hak Anak (Convention on the Rights of the Child) sebagaimana telah diratifikasi oleh Pemerintah Republik Indonesia dengan Keputusan Presiden Nomor 36 Tahun 1990 tentang Pengesahan Convention on the Rights of the Child (Konvensi tentang Hak-Hak Anak). Undang-Undang Nomor 3 Tahun 1997

10 Yulianto Achmad dan Mukti Fajar, Dualisme Penelitian Hukum Normatif \& Empiris, Pustaka Pelajar, Yogyakarta, 2010, hlm. 184.

11 Marlina, Peradilan Pidana Anak Di Indonesia Pengembangan Konsep Diversi dan Keadilan Restoratif, Refika Aditama, Bandung, 2009, hlm. 198

12 R. Wiyono, Sistem Peradilan Pidana Anak di Indonesia, Sinar Grafika, Jakarta, 2016, hlm. 47. 
tentang Pengadilan Anak, dahulu digunakan sebagai dasar dalam pelaksanaan proses peradilan terhadap anak yang melakukan tindak pidana dimaksudkan untuk melindungi dan mengayomi anak yang berhadapan dengan hukum agar anak dapat menyongsong masa depannya yang masih panjang serta memberi kesempatan kepada anak agar melalui pembinaan akan diperoleh jati dirinya untuk menjadi manusia yang mandiri, berguna bagi diri sendiri, keluarga, masyarakat serta bangsa dan negara.

Namun dalam pelaksanaannya, anak justru diposisikan sebagai objek, serta perlakuan terhadap anak berhadapan dengan hukum cenderung merugikan anak, selain itu Undang Undang tentang Pengadilan Anak tersebut sudah tidak sesuai lagi dengan kebutuhan hukum dalam masyarakat dan belum secara komprehensif memberikan perlindungan khusus kepada anak yang berhadapan dengan hukum. Hal itulah yang menjadi pertimbangan pemerintah mengeluarkan UU SPPA yang mengatur mengenai keseluruhan proses penyelesaian perkara anak yang berhadapan dengan hukum mulai tahap penyelidikan sampai dengan tahap pembimbingan setelah menjalani pidana. ${ }^{13}$

Pelaksanaan diversi sebagai pelindungan bagi anak yang berkonflik dengan hukum secara tersirat sudah diatur dalam Konvensi Hak-Hak Anak yang telah diratifikasi oleh Pemerintah Negara Indonesia dengan Keppres No. 36 Tahun 1990 tentang Pengesahan Convention on The Rights of The Child. Berdasarkan Pasal 37 Konvensi Hak-Hak Anak disebutkan bahwa penangkapan, penahanan atau penghukuman anak akan disesuaikan dengan undang-undang dan akan digunakan hanya sebagai langkah terakhir dan untuk masa yang paling singkat dan layak. Lebih lanjut dituangkan dalam Pasal 40 ayat (3) huruf b Konvensi HakHak Anak.

"Negara-negara peserta akan berusaha untuk meningkatkan penetapan undaang-undang, prosedur-prosedur, kekuasaan dan lembaga-lembaga yang dapat diterapkan secara khusus terhadap anak-anak yang disangka, dituduh, atau diakui telah melanggar undang-undang hukum pidana, dan khususnya dimana layak dan dikehendaki, langkah-langkah untuk menangani anakanak seperti itu tanpa mengenakan tindaakan hukum, asal saja hak-hak asasi dan perlindungan-perlindungan hukum seperlunya dihormati."14

Konsep diversi didasarkan pada kenyataan bahwa proses peradilan pidana terhadap anak yang berkonflik dengan hukum melalui sistem peradilan pidana

\footnotetext{
13 Yati Sharfina Desiandri, 'Diversi Terhadap Anak yang Berkonflik dengan Hukum di Tingkat Penyidikan”, USU Law Journal, Vol. 5 No. 1 (Januari 2017), hlm. 147-157

14 Joni, M. dan Zulchaina Z. Tanamas, Aspek Hukum Perlindungan Anak dalam Perspektif Konvensi Hak Anak, Citra Aditya Bakti, Bandung, 1999, hlm. 69
} 
lebih banyak menimbulkan bahaya daripada kebaikan. Kebijakan formulasi hukum pidana merupakan bagian dari pelaksanaan suatu politik hukum pidana dalam hal perumusan materi maupun pasal-pasal yaitu mewujudkan peraturanperaturan yang baik sesuai dengan keadaan dan situasi pada suatu waktu. Kebijakan formulasi/legislatif merupakan salah satu bagian dari fungsionalisasi kebijakan hukum pidana dalam pencegahan dan penanggulangan tindak pidana. Kebijakan formulasi menjadi akses awal yang paling strategis dalam upaya memberikan pelindungan dan keadilan bagi korban tindak pidana.

Kebijakan formulasi hukum pidana tentang diversi sebagai pelindungan bagi anak yang berkonflik dengan hukum dapat dilihat dalam pasal-pasal yang tertuang dalam UU SPPA. Pasal 1 angka 3 UU SPPA mengatur bahwa anak yang berkonflik dengan hukum yang selanjutnya disebut dengan anak adalah anak yang telah berumur 12 tahun, tetapi belum berumur 18 tahun yang diduga melakukan tindak pidana. Pasal tersebut memberikan pelindungan terhadap anak yang berkonflik dengan hukum berdasarkan batasan umurnya. ${ }^{15}$

Asas-asas dalam pelaksanaan sistem peradilan pidana anak sebagaimana telah diuraikan di atas secara substansi telah sesuai dengan asas pelindungan terhadap anak yang tertuang dalam Konvensi Hak-Hak Anak. Hal ini dapat diartikan bahwa kebijakan yang diambil pemerintah dalam menyusun undangundang tentang Sistem Peradilan Pidana Anak sejalan dengan yang telah disepakati oleh bangsa-bangsa di dunia yang telah meratifikasi Konvensi HakHak Anak tersebut.

Banyaknya tindak pidana yang dilakukan oleh anak mengakibatkan adanya upaya guna mencegah dan menanggulanginya, salah satunya adalah penyelenggaraan Sistem Peradilan Pidana Anak (Juvenile Criminal Justice System). Sebagaimana telah diuraikan sebelumnya bahwa UU SPPA mengatur tentang diversi sebagai upaya pengalihan penyelesaian perkara anak dari proses peradilan pidana ke proses di luar peradilan pidana. UU SPPA telah tegas mengatur bahwa upaya diversi wajib dilakukan dalam setiap tahapan dalam suatu proses peradilan anak mulai dari tahap penyidikan, penuntutan dan pemeriksaan perkara anak di tingkat pengadilan.

Pelaksanaan diversi di Indonesia terdapat syarat-syarat yang dijadikan pedoman oleh aparat penegak hukum. Adapun syarat-syarat diversi tercantum dalam Pasal 8 UU SPPA yang menentukan sebagai berikut:

15 Marlina, Peradilan Pidana Anak di Indonesia "Pengembangan Konsep Diversi dan Restorative Justice", Refika Aditama, Bandung, 2009, hlm. 67 
1. Proses diversi dilakukan melalui musyawarah dengan melibatkan Anak dan orang tua/Walinya, Pembimbing Kemasyarakatan, dan Pekerja Sosial Profesional berdasarkan pendekatan Keadilan Restoratif.

2. Dalam hal diperlukan, musyawarah sebagaimana dimaksud pada ayat (1) dapat melibatkan Tenaga Kesejahteraan Sosial, dan/atau masyarakat.

3. Proses diversi wajib memperhatikan:
a. Kepentingan korban.
b. Kesejahteraan dan tanggung jawab Anak.
c. Penghindaran stigma negatif.
d. Penghindaran pembalasan.
e. Keharmonisan masyarakat.
f. Kepatutan, kesusilaan, dan ketertiban umum.

Kemudian di dalam Pasal 9 UU SPPA, terdapat juga ketentuan mengenai pelaksanaan diversi sebagai berikut:

1. Penyidik, Penuntut Umum, dan Hakim dalam melakukan Diversi harus mempertimbangkan:
a. Kategori tindak pidana.
b. Umur anak.
c. Hasil penelitian kemasyarakatan dari Bapas.
d. Dukungan lingkungan keluarga dan masyarakat.

2. Kesepakatan Diversi harus mendapatkan persetujuan korban dan/atau keluarga Anak Korban serta kesediaan Anak dan keluarganya, kecuali untuk:
a. Tindak pidana yang berupa pelanggaran.
b. Tindak pidana ringan.
c. Tindak pidana tanpa korban.
d. Nilai kerugian korban tidak lebih dari nilai upah minimum provinsi setempat.

Adapun beberapa kriteria tindak pidana yang melibatkan anak sebagai pelaku, yang harus diupayakan penyelesaiannya dengan pendekatan prinsip diversi adalah sebagai berikut:

a. Kategori tindak pidana yang diancam dengan sanksi pidana sampai dengan 1 tahun harus diprioritaskan untuk diterapkan diversi. Tindak pidana yang diancam dengan sanksi pidana di atas 1 tahun sampai dengan 5 tahun dapat dipertimbangkan untuk melakukan diversi. Semua kasus pencurian harus diupayakan penerapan diversi kecuali menyebabkan atau menimbulkan kerugian yang terkait dengan tubuh dan jiwa.

b. Memerhatikan usia pelaku, semakin muda usia pelaku, maka urgensi penerapan prinsip diversi semakin diperlukan. 
c. Hasil penelitian dari BAPAS, bila ditemukan faktor pendorong anak terlibat dalam kasus pidana adalah faktor yang ada di luar kendali anak maka penerapan prinsip diversi semakin diperlukan.

d. Kerugian yang ditimbulkan oleh tindak pidana anak, bila akibat yang ditimbulkan bersifat kebendaan dan tidak terkait dengan tubuh dan nyawa seseorang maka penerapan diversi semakin diperlukan.

e. Tingkat keresahan masyarakat yang diakibatkan oleh perbuatan anak.

f. Persetujuan korban/keluarga.

g. Kesediaan pelaku dan keluarganya.

h. Dalam hal anak melakukan tindak pidana bersama-sama orang dewasa maka orang dewasa harus diproses hukum sesuai dengan prosedur biasa.

Kendala yang dihadapi Aparat Penegak Hukum dalam pelaksanaan Diversi tindak pidana narkotika anak setelah berlakunya Perma Nomor 4 Tahun 2014 Tentang Pedoman Pelaksanaan Diversi dalam Sistem Peradilan Anak

Diversi tidak hanya dilakukan sebatas memberikan keringanan hukuman bagi anak. Tujuan penerapan diversi adalah untuk melindungi hak anak sebagai pelaku tindak pidana. Penerapan diversi dapat dilakukan terhadap tindak pidana yang ancaman pidananya di bawah 7 tahun penjara dan bukan merupakan tindak pidana pengulangan.

Tindak pidana narkotika merupakan salah satu tindak pidana yang sering dikaitkan dengan ancaman yang tinggi. Pasal 7 ayat (2) UU SPPA mengatur bahwa tindak pidana yang diancam di atas 7 tahun penjara maka tidak bisa diterapkan diversi. Sedangkan menurut Pasal 3 Perma Nomor 4 Tahun 2014 tentang Pedoman Pelaksanaan Diversi dalam Sistem Peradilan Pidana Anak mengatur bahwa Hakim anak wajib mengupayakan diversi dalam hal anak didakwa melakukan tindak pidana yang diancam dengan pidana penjara di bawah 7 tahun dan didakwa pula dengan tindak tindak pidana yang diancam dengan pidana penjara 7 tahun atau lebih dalam bentuk surat dakwaan subsidaritas, alternatif, kumulatif maupun kombinasi (gabungan). Kedua peraturan ini menjadi tidak sinkron dalam mengatur sebuah permasalahan. Hal inilah yang menjadi kendala dalam penyelesaian perkara tindak pidana narkotika yang dilakukan oleh anak di bawah umur. ${ }^{16}$

Terkait dengan peraturan yang menjelaskan tentang diversi ini terdapat 2 peraturan yang mengaturnya yaitu Undang-Undang Nomor 11 Tahun 2012 tentang Sistem Peradilan Pidana Anak dan Perma Nomor 4 Tahun 2014 tentang Pedoman Pelaksanaan Diversi dalam Sistem Peradilan Pidana Anak. Dalam

16 Wawancara dengan Ibu Ikha Tina, Hakim Anak Pengadilan Negeri Sleman, Tgl. 28 Februari 2018 
Undang-Undang Nomor 11 Tahun 2012 tentang Sistem Peradilan Pidana Anak menjelaskan diversi dapat dilakukan terhadap tindak pidana yang didakwa di bawah 7 tahun penjara. Hal ini yang membuat hakim sebagai aparat penegak hukum menjadi bingung mana yang lebih baik digunakan, jika hakim menggunakan Perma lebih menjujung keadilan terhadap anak tetapi hakim tidak bisa secara sepihak karena instansi lain jarang menggunakan peraturan tersebut. ${ }^{17}$

Hakim anak lebih berpedoman kepada UU SPPA daripada Perma Nomor 4 Tahun 2014 Tentang Pedoman Pelaksanaan Diversi dalam Sistem Peradilan Pidana Anak. Hakim Anak melakukan demikian karena melihat juga para penegak hukum yang lain lebih menggunakan UU SPPA. UU SPPA secara hierarkis dianggap paling tinggi walaupun Perma Nomor 4 Tahun 2014 tentang Pedoman Pelaksanaan Diversi dalam Sistem Peradilan Pidana Anak berlaku keluar, yang juga berlaku bagi aparat penegak hukum lainnya.

Penegak hukum yang lain beranggapan bahwa kurang tepat jika Hakim Peradilan Anak menggunakan peraturan yang bukan merupakan terbitan dari instansinya (Mahkamah Agung). Sebagaimana terungkap dari wawancara dengan Galan Adid Darmawan, selaku Kepala Satuan Reserse Narkoba Polres Sleman dan Andri Kristanto selaku Jaksa Anak pada Kejaksaan Negeri Sleman. Kepolisian pada dasarnya juga berpedoman pada UU SPPA yang mengatur lebih umum dan juga mencakup seluruh warga negara Indonesia. Akan tetapi jika kasus yang bersangkutan bisa atau lebih baik diatasi dengan Perma Nomor 4 Tahun 2014 tentang Pedoman Pelaksanaan Diversi dalam Sistem Peradilan Pidana Anak maka polisi dapat saja menggunakan peraturan tersebut, tetapi polisi lebih berpedoman pada UU SPPA. ${ }^{18}$

Kejaksaan juga tetap berpedoman terhadap UU SPPA daripada Perma Nomor 4 Tahun 2014 tentang Pedoman Pelaksanaan Diversi karena Perma ini merupakan terbitan dari Mahkamah Agung walaupun bersifat keluar. Jaksa biasanya juga memiliki acuan surat edaran dari Kepala Kejaksaan sehingga Jaksa tidak menggunakan pedoman dari instansi lain. Meski demikian, Jaksa juga mengupayakan agar Perma Nomor 4 Tahun 2014 tentang Pedoman Pelaksanaan Diversi dapat digunakan/diterapkan di Pengadilan dengan cara jaksa membuat dakwaan yang subsidaritas, agar dapat menjadi pertimbangan hakim sendiri. ${ }^{19}$

${ }^{17}$ Ibid.

18 Wawancara Wawancara dengan Galan Adid Darmawan, selaku Kepala Satuan Reserse Narkoba Polres Sleman Tgl. 7 Maret 2019.

${ }^{19}$ Wawancara dengan Andri Kristanto Jaksa Anak Kejaksaan Negeri Sleman, Sleman, Tgl. 2 Maret 2019 
Kendala penerapan diversi dalam tindak pidana narkotika yang dilakukan oleh anak selain karena perbedaan pandangan pedoman ataupun ketidaksinkronan antara UU SPPA dengan Perma Nomor 4 Tahun 2014 tentang Pedoman Pelaksanaan Diversi adalah proses diversi dalam hal tindak pidana narkotika yang dianggap sebagai tindak pidana tanpa korban hanya dapat dilakukan oleh penyidik, dalam hal ini hanya kepolisian yang dapat melakukan proses diversi. Diversi dalam tindak pidana narkotika yang dianggap sebagai tindak pidana tanpa korban ini diatur dalam Pasal 9 dan Pasal 10 UU SPPA. Pasal 9 UU SPPA mengatur bahwa diversi harus mempertimbangkan tindak pidananya, di mana tindak pidana narkotika adalah jenis tindak pidana tanpa korban. Pasal 10 UU SPPA mengatur pula bahwa tindak pidana yang masuk ke dalam jenis tindak pidana narkotika hanya boleh dilakukan diversi oleh penyidik, dalam hal ini kepolisian yang boleh melakukan diversi terhadap tindak pidana narkotika.

\section{Penutup}

Berdasarkan analisis di atas, maka penelitian ini menyimpulkan: pertama, penerapan diversi dalam tindak pidana narkotika menurut Perma Nomor 4 Tahun 2014 tentang Pedoman Pelaksanaan Diversi dalam Sistem Peradilan Pidana Anak masih belum dilaksanakan. Penyidik dan penuntut umum menilai bahwa Perma merupakan produk dari Mahkamah Agung yang dianggap hanya dapat dipergunakan atau berlaku terhadap aparat di bawah Mahkamah Agung. Penyidik dan penuntut umum masih enggan menggunakan Perma dikarenakan kedua instansi ini memilih berpedoman pada UU SPPA karena penyidik dan penuntut umum beraggapan bahwa UU SPPA merupakan peraturan yang lebih tinggi dibanding Perma dan berlakunya lebih luas.

Hakim pengadilan di bawah naungan Mahkamah Agung terkadang tetap berpedoman kepada UU SPPA daripada Perma, hal ini dikarenakan mereka merasa resah apabila dianggap melanggar UU. Berdasarkan UU SPPA, penerapan diversi dapat dilakukan terhadap perkara yang ancaman pidanya di bawah 7 tahun sedangkan dalam Perma Nomor 4 Tahun 2014 penerapan diversi dapat dilakukan terhadap perkara yang ancama pidananya di atas 7 tahun tetapi dakwaannya bersifat subsidaritas, alternatif, atau kumulatif yang salah satu dakwaannya ada ancaman pidana di bawah 7 tahun harus dilakukan diversi.

Kedua, kendala dalam penerapan diversi dalam tindak pidana narkotika setelah berlakunya Perma Nomor 4 Tahun 2014 adalah para penegak hukum beranggapan bahwa tindak pidana narkotika merupakan tindak pidana yang didakwa tinggi sekalipun dakwaannya alternatif. Perma Nomor 4 Tahun 2014 
mewajibkan diversi dalam tindak pidana yang didakwa dengan dakwaan alternatif, hal ini terjadi karena para penegak hukum jarang menggunakan Perma Nomor 4 Tahun 2014. Selain tidak menerapkan Perma Nomor 4 Tahun 2014, kendala lainya adalah tindak pidana narkotika merupakan tindak pidana tanpa korban sehingga penerapan diversi hanya dapat dilakukan di penyidik, hal inilah yang membuat penuntut umum dan hakim jarang menerapkan diversi dalam tindak pidana narkotika.

Para penegak hukum seharusnya tidak dengan mudah begitu saja melepaskan diversi dalam tindak pidana narkotika tetapi juga mencermati bahwa diversi dalam tindak pidana anak wajib dilakukan sekalipun tindak pidana itu tanpa korban. Para penegak hukum seharusnya dapat menjunjung tinggi keadilan terhadap anak yang anak sendiri memiliki keistimewaan dan hak-hak yang harus dijaga agar kedepannya anak dapat diarahkan untuk bisa tumbuh dan berkembang dengan baik mengingat anak merupakan generasi penerus bangsa.

\section{Daftar Pustaka}

\section{Buku}

Achmad, Yulianto dan Mukti Fajar, Dualisme Penelitian Hukum Normatif \& Empiris, Pustaka Pelajar, Yogyakarta, 2010.

Kusuma, Mulyana W, Hukum dan Hak-Hak Anak, CV. Rajawali, Jakarta, 1986.

Marlina, Pengantar Konsep Diversi dan Restorative Justice, USU Press, Medan, 2010. Peradilan Pidana Anak di Indonesia (Pengembangan Konsep Diversi), Refika Aditama, Bandung, 2012.

Marzuki, Peter Mahmud, Penelitian Hukum Edisi Revisi, Prenadamedia Group, Jakarta, 2016.

Prodjodikoro, Wirjono, Asas-Asas Hukum Pidana Indonesia. PT. Eresco, Bandung, 1989.

Sambas, Nandang, Pemberharuan Sistem Pemidanaan Anak di Indonesia, Graha Ilmu, Yogyakarta, 2010.

Soekanto, Soerjono dan Sri Mamudji, Penelitian Hukum Normatif, Rajawali, Jakarta, 1985.

\section{Jurnal}

Yati Sharfina Desiandri, "Diversi Terhadap Anak yang Berkonflik dengan Hukum di Tingkat Penyidikan", USU Law Journal, Vol. 5 No. 1, Januari 2017.

\section{Website}

http://www.hukumonline.com/berita/baca/lt5475dd3e4d788/icjr, Aparat Hukum Belum Paham Arti Diversi. Diakses pada tanggal 28 Maret 2017 pukul 10.26 
http:/ / www.hukumonline.com/berita/baca/lt4e25360a422c2 Jecky Tengens, SH, Pendekatan Restorative Justice dalam Sistem Pidana Indonesia. Diakses pada tanggal 25 Oktober 2017 pukul 11.56

\section{Peraturan Perundang-undangan}

Kitab Undang-Undang Hukum Acara Pidana (KUHAP)

Kitab Undang-Undang Hukum Pidana (KUHP)

Undang-Undang Nomor 1 Tahun 1946 tentang Peraturan Hukum Pidana

Undang-Undang Nomor 8 Tahun 1996 tentang Pengesahan Convention On Psychotropic Substance 1971 (Konvensi Psikotropika 1971)

Undang-Undang Nomor 35 Tahun 2009 tentang Narkotika

Undang-Undang No. 11 Tahun 2012 tentang Sistem Peradilan Pidana Anak

Peraturan Mahkamah Agung Nomor 4 Tahun 2014 tentang Pedoman Pelaksaan Diversi dalam Sistem Peradilan Pidana Anak

Putusan Pengadilan

PUTUSAN NOMOR : 6/PID.Sus.Anak/2015/PT.MDN.

PUTUSAN NOMOR : 28/Pid.Sus-Anak/2017/PN Smn. 